Article

\title{
Amaryllidaceae Alkaloids of Belladine-Type from Narcissus pseudonarcissus cv. Carlton as New Selective Inhibitors of Butyrylcholinesterase
}

\author{
Abdullah Al Mamun ${ }^{1}{ }^{(0}$, Jana Maříková ${ }^{2}$, Daniela Hulcová ${ }^{1,3}$, Jiří Janoušek ${ }^{1,3}$ (D), \\ Marcela Šafratová 1,3, Lucie Nováková ${ }^{4}$, Tomáš Kučera ${ }^{5}$, Martina Hrabinová ${ }^{6,7}$, Jiří Kuneš ${ }^{2}$, \\ Jan Korábečný ${ }^{6,7, *(D)}$ and Lucie Cahlíková ${ }^{1, *(D)}$ \\ 1 ADINACO Research Group, Department of Pharmaceutical Botany, Faculty of Pharmacy, Charles University, \\ Heyrovského 1203, 50005 Hradec Králové, Czech Republic; almamuna@faf.cuni.cz (A.A.M.); \\ hulcovd@faf.cuni.cz (D.H.); janousj2@faf.cuni.cz (J.J.); safratom@faf.cuni.cz (M.Š.) \\ 2 Department of Organic and Bioorganic Chemistry, Faculty of Pharmacy, Charles University, \\ Heyrovského 1203, 50005 Hradec Králové, Czech Republic; marikoj2@faf.cuni.cz (J.M.); \\ kunes@faf.cuni.cz (J.K.) \\ 3 Department of Pharmacognosy, Faculty of Pharmacy, Charles University, Heyrovského 1203, \\ 50005 Hradec Králové, Czech Republic \\ 4 Department of Analytical Chemistry, Faculty of Pharmacy, Charles University, Heyrovského 1203, \\ 50005 Hradec Králové, Czech Republic; novakoval@faf.cuni.cz \\ 5 Department of Military Medical Service Organisation and Management, Faculty of Military Health Sciences, \\ University of Defence, Třebešská 1575, 50005 Hradec Králové, Czech Republic; kucera-t@email.cz \\ 6 Department of Toxicoloxy and Military Pharmacy, Faculty of Military Health Sciences, University of Defence, \\ Třebešská 1575, 50005 Hradec Králové, Czech Republic; hrabinova@pmfhk.cz \\ 7 Biomedical Research Centre, University Hospital Hradec Kralove, Sokolska 581, \\ 50005 Hradec Kralove, Czech Republic \\ * Correspondence: jan.korabecny@fnhk.cz (J.K.); cahlikova@faf.cuni.cz (L.C.); \\ Tel.: +420-495-067-311 (L.C.); +420-495-833-447 (J.K.)
}

Received: 30 April 2020; Accepted: 19 May 2020; Published: 22 May 2020

\begin{abstract}
Thirteen known (1-12 and 16) and three previously undescribed Amaryllidaceae alkaloids of belladine structural type, named carltonine A-C (13-15), were isolated from bulbs of Narcissus pseudonarcissus cv. Carlton (Amaryllidaceae) by standard chromatographic methods. Compounds isolated in sufficient amounts, and not tested previously, were evaluated for their in vitro acetylcholinesterase (AChE; E.C. 3.1.1.7), butyrylcholinesterase (BuChE; E.C. 3.1.1.8) and prolyl oligopeptidase (POP; E.C. 3.4.21.26) inhibition activities. Significant human BuChE ( $h \mathrm{BUChE}$ ) inhibitory activity was demonstrated by newly described alkaloids carltonine A (13) and carltonine B (14) with $\mathrm{IC}_{50}$ values of $913 \pm 20 \mathrm{nM}$ and $31 \pm 1 \mathrm{nM}$, respectively. Both compounds displayed a selective inhibition pattern for $h \mathrm{BuChE}$ with an outstanding selectivity profile over $\mathrm{AChE}$ inhibition, higher than 100 . The in vitro data were further supported by in silico studies of the active alkaloids $\mathbf{1 3}$ and $\mathbf{1 4}$ in the active site of $h \mathrm{BuChE}$.
\end{abstract}

Keywords: Amaryllidaceae; Narcissus pseudonarcissus cv. Carlton; alkaloids; carltonine A-C; Alzheimer's disease; butyrylcholinesterase; docking studies

\section{Introduction}

Alzheimer's disease (AD), a progressive neurodegenerative brain disorder featuring memory loss and cognitive impairments, has been named after German psychiatrist Alois Alzheimer. AD is the most common type of dementia among the elderly, generally diagnosed in individuals over the age of 
65 years [1]. Considering population aging and increased life expectancy, the number of AD patients is predicted to increase enormously. About 4.6 million new cases are diagnosed every year throughout the world, and the World Health Organization (WHO) estimates that by 2050 over 131 million patients will suffer from AD [2]. Additionally, the current cost of dementia is about a trillion US dollars per year, and it should rise to 2 trillion US dollars by 2030 [3]. Thus, AD starts to be one of the greatest public health problems with severe impact on patients, their families and care workers.

Although the exact pathogenesis of $\mathrm{AD}$ remains elusive, it is currently conceived as a multifactorial disease. The main pathological hallmarks of $A D$ are the deposits of $\beta$-amyloid peptide $(A \beta)$ in senile plaques and neurofibrillary tangles (NFTs) formed by hyperphosphorylated $\tau$-protein [4]. In addition to them, inflammation and oxidative stress processes also extensively contribute to the loss of synaptic integrity and neurodegeneration.

The current treatment is only symptomatic and mainly involves restoring of acetylcholine (ACh) levels through AChE inhibition [5]. Three AChE inhibitors, namely donepezil, galanthamine and rivastigmine, are currently used as the main therapeutic option for $\mathrm{AD}$ treatment [6]. BuChE is another serine hydrolase homologous to AChE that is encoded by a different gene and can be found ubiquitously throughout the body [6]. The role of $\mathrm{BuChE}$ has recently gained enormous interest, and not only in the field of AD research [7]. Regarding AD, it is well-documented that AChE activity is downregulated by up to $33-45 \%$ of normal values, while the activity of $\mathrm{BuChE}$ is escalated by up to 40-90\% [8]. This dramatic switch between the AChE/BuChE ratio highlighted the supportive role of $\mathrm{BuChE}$ in hydrolysing the excess of $\mathrm{ACh}$. Moreover, several lines of evidence also indicate that both cholinesterases play an important role in $A \beta$ aggregation and maturation to oligomers, fibrils and plaques [9].

POP, a cytosolic serine peptidase, has gained interest as a target for the treatment of neuropsychiatric and neurodegenerative diseases like schizophrenia, bipolar affective disorder, Parkinson's disease and $\mathrm{AD}$ [10]. POP is expressed in several brain regions, and catalyses with high specificity the cleavage of short peptides containing proline at its carboxyl site [11]. POP is responsible for the degradation of neurotransmitters, such as substance $P$, arginine vasopressin-oxytocin, and neurotensin, which in turn reduce the possibility of generation of toxic A $\beta$ peptides. Generally, POP can be regarded as one of the active players in the processes of learning and memory. In fact, some POP inhibitors have been experimentally found to act as antidementia drugs [10].

Natural products represent an important source of clinical drugs, especially for their structural diversity and wide range of biological activities [12]. Alkaloids are, without a doubt, the most intriguing templates of natural origin [13]. The family Amaryllidaceae comprises about 1100 species in 85 genera, which are distributed worldwide through the tropics and warm regions [14]. Some of the species are cultivated as ornamental plants for their beautiful flowers and fragrant essences. Different types of plant extracts from this family have been long used in traditional medicine for the treatment of cancer by the ancient Greeks, as well as by Africans, Asians, and Polynesian communities for the treatment of various diseases $[15,16]$. The medicinal value of the Amaryllidaceae species is attributed to the presence of tyrosine-derived alkaloids, typically named as Amaryllidaceae alkaloids (AAs), that are produced exclusively by this family. These alkaloids exhibit a wide range of biological activities, including AChE inhibition, antitumor, antiviral, antimalarial, analgesic antibacterial, and cytotoxic properties. One successful example of an Amaryllidaceae alkaloid is exemplified by galanthamine, a drug indicated for the treatment of mild to moderate vascular dementia and AD [17].

Narcissus L. is the most common genus of the Amaryllidaceae family comprising 80-100 wild species, mainly distributed in Southwestern Europe and North Africa, with some populations in the Balkans, Italy and France. Plants of the genus Narcissus L. have been used in traditional medicine worldwide in cancer therapy [18-21]. Most of the species can hybridize, thus, a large number of cultivars have been developed for ornamental purposes. Interestingly, some intersectional hybrids and cultivars have also been reported as potential sources of galanthamine and other Amaryllidaceae alkaloids [22,23]. The cultivar Carlton is cultivated for the commercial extraction of galanthamine, 
because of its relatively high concentration in the bulbs, the large bulb size, and their availability in large volumes. Galanthamine is reported as the major alkaloid of Narcissus pseudonarcissus, followed by haemanthamine. Haemanthamine also has interesting biological activities including inhibition of protein synthesis, antimalarial and antiretroviral activity, as well as cytotoxicity against various cancer cell lines [24-26]. Recently, some semi-synthetic derivatives of haemanthamine have been published as promising candidates for AD therapy [27].

As a part of our ongoing research on Amaryllidaceae alkaloids with implication to AD, this work reports the isolation of several such alkaloids from fresh bulbs of Narcissus pseudonarcissus cv. Carlton. The isolated alkaloids that had not been previously studied were submitted for biological evaluation to reveal their inhibition potential towards $h \mathrm{AChE}, h \mathrm{BuChE}$, and POP. In vitro data were further supported by investigating the compound's putative binding modes in the active site of $h \mathrm{BuChE}$ to display crucial interaction.

\section{Results and Discussion}

\subsection{Phytochemical Study of Narcissus pseudonarcissus cv. Carlton}

Thirteen known (1-12 and 16) and three novel AAs (13-15) were isolated from bulbs of Narcissus pseudonarcissus cv. Carlton (Amaryllidaceae) by common chromatographic methods, as described in the Experimental section. The compounds were identified by MS, ESI-HRMS, 1D and 2D NMR spectroscopic analyses and by comparison of the obtained data with the literature (Figure 1). These techniques led to the identification of lycosinine B (1) [28], trisphaeridine (2) [29], 3,4-anhydrogalanthamine (3) [30], oduline (4) [31], masonine (5) [32], galanthamine (6) [33], galanthine (7) [34], lycorenine (8) [33], lycoramine (9) [33], homolycorine (10) [31], haemanthamine (11) [20], vittatine (12) [35], and 9-O-demethylhomolycorine (16) [31]. The isolated alkaloids belong to the galanthindole (1), narciclasine (2), galanthamine $(3,6,9)$, homolycorine $(4,5,8,10,16)$, lycorine $(7)$ and haemanthamine $(\mathbf{1 1}, \mathbf{1 2})$ structural types; newly isolated alkaloids $\mathbf{1 3 - 1 5}$ belong to the beladinne-type of AAs.

The new compound 13, named carltonine A, was obtained as a pale yellow oil. The HRMS of $\mathbf{1 3}$ showed a protonated molecular ion peak $\left[\mathrm{M}+\mathrm{H}^{+}\right.$at $\mathrm{m} / \mathrm{z} 433.2488$, corresponding to the molecular formula $\mathrm{C}_{27} \mathrm{H}_{32} \mathrm{~N}_{2} \mathrm{O}_{3}$ (433.2486 calcd for $\mathrm{C}_{27} \mathrm{H}_{33} \mathrm{~N}_{2} \mathrm{O}_{3}{ }^{+}$). The ${ }^{1} \mathrm{H}$ NMR spectrum exhibited resonances associated with nine aromatic protons from which the presence of a $p$-substituted benzene ring $\left(\delta_{\mathrm{H}}\right.$ 7.00-6.96; 6.72-6.68), a 1,2,4,5-tetrasubstituted benzene ring $\left(\delta_{\mathrm{H}} 7.10,6.76\right)$ and a 1,2,3-trisubstituted benzene ring $\left(\delta_{\mathrm{H}} 7.09,6.82,6.72\right)$ were obvious. The high-field part of the ${ }^{1} \mathrm{H}$ NMR spectrum contained one singlet corresponding to two methoxy groups $\left(\delta_{\mathrm{H}} 3.34\right)$, two doublets $\left(\delta_{\mathrm{H}} 3.45,3.29\right)$, two doublets of triplets $\left(\delta_{\mathrm{H}} 3.32\right.$, dt, overlap, $\left.J=17.3,8.8 \mathrm{~Hz} ; 3.20, \mathrm{dt}, J=17.3,8.8 \mathrm{~Hz}\right)$, two triplets $\left(\delta_{\mathrm{H}} 2.98, \mathrm{t}, J=8.8 \mathrm{~Hz}\right.$; $2.65, \mathrm{t}, J=7.4 \mathrm{~Hz})$ and two singlets of $N$-methyl groups $\left(\delta_{\mathrm{H}} 2.21,2.20\right)$. The ${ }^{13} \mathrm{C}$ and $\mathrm{HSQC}$ data revealed signals of four deshielded $\mathrm{sp}^{2}$ carbons $\left(\delta_{\mathrm{C}} 154.0,150.4,148.1,146.9\right)$, five nonprotonated $\mathrm{sp}^{2}$ carbons $\left(\delta_{C} 132.5,132.1,131.2,130.1,123.0\right)$, seven aromatic methines $\left(\delta_{C} 130.5,129.8(2 \mathrm{C}), 123.3,117.9,115.1\right.$ (2C), 113.2, 111.1), three deshielded methylenes $\left(\delta_{C} 59.2,58.5,57.1\right)$, two methoxy groups $\left(\delta_{C} 55.9,55.8\right)$, two $N$-methyls $\left(\delta_{C} 42.3,38.6\right)$ and two aliphatic methylene groups $\left(\delta_{C} 32.8,28.6\right)$. The COSY spectrum, supported by H2BC correlations, showed cross-peaks for the $\mathrm{H}-1 / \mathrm{H}-2, \mathrm{H}-2^{\prime \prime} / \mathrm{H}-3^{\prime \prime}, \mathrm{H}-4^{\prime \prime} / \mathrm{H}-5^{\prime \prime} / \mathrm{H}-6^{\prime \prime}$ and $\mathrm{AA}^{\prime} \mathrm{BB}^{\prime}$ spin systems. Moreover, these assignments corresponded to the spin-spin splitting of signals in the ${ }^{1} \mathrm{H}$ spectrum. HMBC correlation from $\mathrm{H}-2$ to the $\mathrm{sp}^{2}$ carbons at $\delta_{\mathrm{C}} 129.8$ revealed the fact that the $p$-substituted benzene ring was attached to the aminoethyl group. The nitrogen from this substructural fragment bore a methyl at $\delta_{C} 42.3$ and a benzylic methylene at $\delta_{C} 58.5$. The 1,2,4,5-tetrasubstituted aromatic ring was determined by $\mathrm{HMBC}$ correlations from $\mathrm{H}-4^{\prime}$ and $\mathrm{H}-7^{\prime}$. This experiment also revealed the conjunction of this fragment with the methylene $\mathrm{C}-1^{\prime}$ by $\mathrm{C}-2^{\prime}$. The HMBC cross-peaks of $\delta_{\mathrm{H}} 6.76$ to $\delta_{\mathrm{C}} 123.0$ and $\delta_{\mathrm{H}} 6.82$ to $\delta_{\mathrm{C}} 132.1$ indicated the attachment of nonprotonated carbons $\mathrm{C}-3^{\prime}$ and $\mathrm{C}-7^{\prime \prime}$. This $\mathrm{sp}^{2}$ quaternary carbon belonged to the remaining 1,2,3-trisubsituted aromatic ring which was a part of the $\mathrm{N}$-methylindoline moiety. This was proven by correlation of its protons to the related 
carbons. Therefore, the structure of $\mathbf{1 3}$ was established as depicted (Figure 2). The assigned atoms are shown in Table 1.<smiles>COc1cc(C=O)c(-c2cccc3c2N(C)CC3)cc1OC</smiles>

Lycosinine B (1)<smiles>c1ccc2c(c1)ncc1cc3c(cc12)OCO3</smiles>

Trisphaeridine (2)<smiles>COc1ccc(CN2CC3C=CC=CC3C2Oc2ccccc2)cc1</smiles>

3,4-Anhydrogalanthamine (3)<smiles>CN1CCC2=CCC3OC(=O)c4cc5c(cc4[C@@H]3[C@@]21C)OCO5</smiles>

Masonine (5)<smiles>[R6]Oc1cc2c(cc1O[R6])C1([R4])OC3CC=C4CCN([R])C4C31C2[R]</smiles>

$\mathrm{R}_{1}=\mathrm{Me}, \mathrm{R}_{2}+\mathrm{R}_{3}=\mathrm{CH}_{2}, \mathrm{R}_{4}=\mathrm{OH}, \mathrm{R}_{5}=\mathrm{H} ;$ Oduline $(\mathbf{4})$

$\mathrm{R}_{1}=\mathrm{Me}, \mathrm{R}_{2}=\mathrm{Me}, \mathrm{R}_{3}=\mathrm{Me}, \mathrm{R}_{4}=\mathrm{OH}, \mathrm{R}_{5}=\mathrm{H} ;$ Lycorenine (8)

$R_{1}=M e, R_{2}=M e, R_{3}=M e, R_{4}+R_{5}=0$; Homolycorine (10)

$\mathrm{R}_{1}=\mathrm{Me}, \mathrm{R}_{2}=\mathrm{H}, \mathrm{R}_{3}=\mathrm{Me}, \mathrm{R}_{4}+\mathrm{R}_{5}=\mathrm{O}$; 9-O-Demethylhomolycorine (16)<smiles>COc1ccc2c3c1OC1C[C@H](O)C=CC31CN(C)C2</smiles>

Galanthamine (6)

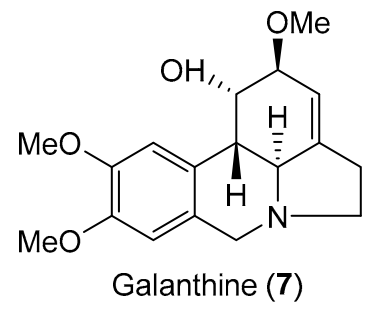<smiles>COc1ccc2c3c1OC1C[C@H](O)CC[C@@]31CCN(C)C2</smiles>

Lycoramine (9)

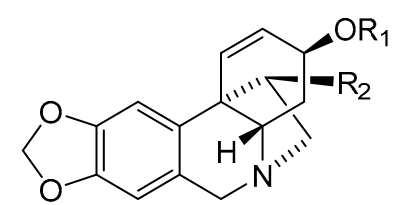

$\mathrm{R}_{1}=\mathrm{Me}, \mathrm{R}_{2}=\mathrm{OH} ;$ Haemanthamine (11) $\mathrm{R}_{1}=\mathrm{H}, \mathrm{R}_{2}=\mathrm{H} ;$ Vitattine (12)

Figure 1. Structures of isolated alkaloids from Narcissus pseudonarcissus cv. Carlton.

Carltonine B (14) was obtained as a pale yellow oil. The molecular formula was determined to be $\mathrm{C}_{26} \mathrm{H}_{28} \mathrm{~N}_{2} \mathrm{O}_{3}$ from the protonated molecular ion peak $[\mathrm{M}+\mathrm{H}]^{+}$found at $m / z 417.2172$ (417.2173 calcd for $\mathrm{C}_{26} \mathrm{H}_{29} \mathrm{~N}_{2} \mathrm{O}_{3}{ }^{+}$) in the positive-ion HRMS. Due to the small quantity of sample, the ${ }^{1} \mathrm{H}$ NMR spectrum had poor resolution, but it looked similar to that of 13 . In addition, the ${ }^{13} \mathrm{C}$ spectrum was in accordance with this observation (see Table 1). The only difference was the absence of signals assigned to two methoxy groups of the 1,2,4,5-tetrasubstituted aromatic fragment, which were replaced by signals corresponding to a strongly deshielded methylene group of a 1,3-dioxole moiety in the 1D spectra. The key correlations are presented in Figure 2.

Another new compound, carltonine C (15), was obtained as a yellowish amorphous solid. The 1D NMR spectrum, as well as the 2D NMR spectra of 15 and 13, were quite similar; however, the ${ }^{13} \mathrm{C}$ NMR data showed doubling of most carbon resonances and the absence of the $\mathrm{N}$-methyl group of the central tertiary nitrogen. Moreover, the molecular formula was determined to be $\mathrm{C}_{44} \mathrm{H}_{49} \mathrm{~N}_{3} \mathrm{O}_{5}$ from the protonated molecular ion peak $[\mathrm{M}+\mathrm{H}]^{+}$found at $\mathrm{m} / \mathrm{z} 700.3743\left(700.3745\right.$ calcd for $\mathrm{C}_{44} \mathrm{H}_{50} \mathrm{~N}_{3} \mathrm{O}_{5}{ }^{+}$). These prerequisites led to the identification of the structure shown in Figure 2. The framed substituents of the central tertiary nitrogen are identical; therefore, there is no reason for doubling the signals, as appeared in the 1D NMR data. Due to the steric hindrance of these two fragments, atropisomerism has been estimated as the reason for the doubling of some signals. The analysis was performed at ambient temperature and at $50{ }^{\circ} \mathrm{C}$. The acquired results proved the suitability of this assumption. At ambient temperature, some signals were divided into two lines that broaden with temperature increase and 
eventually merge into a single line (see Supplementary Material). Unfortunately, the spectrum also revealed the signals of decomposition of this molecule.
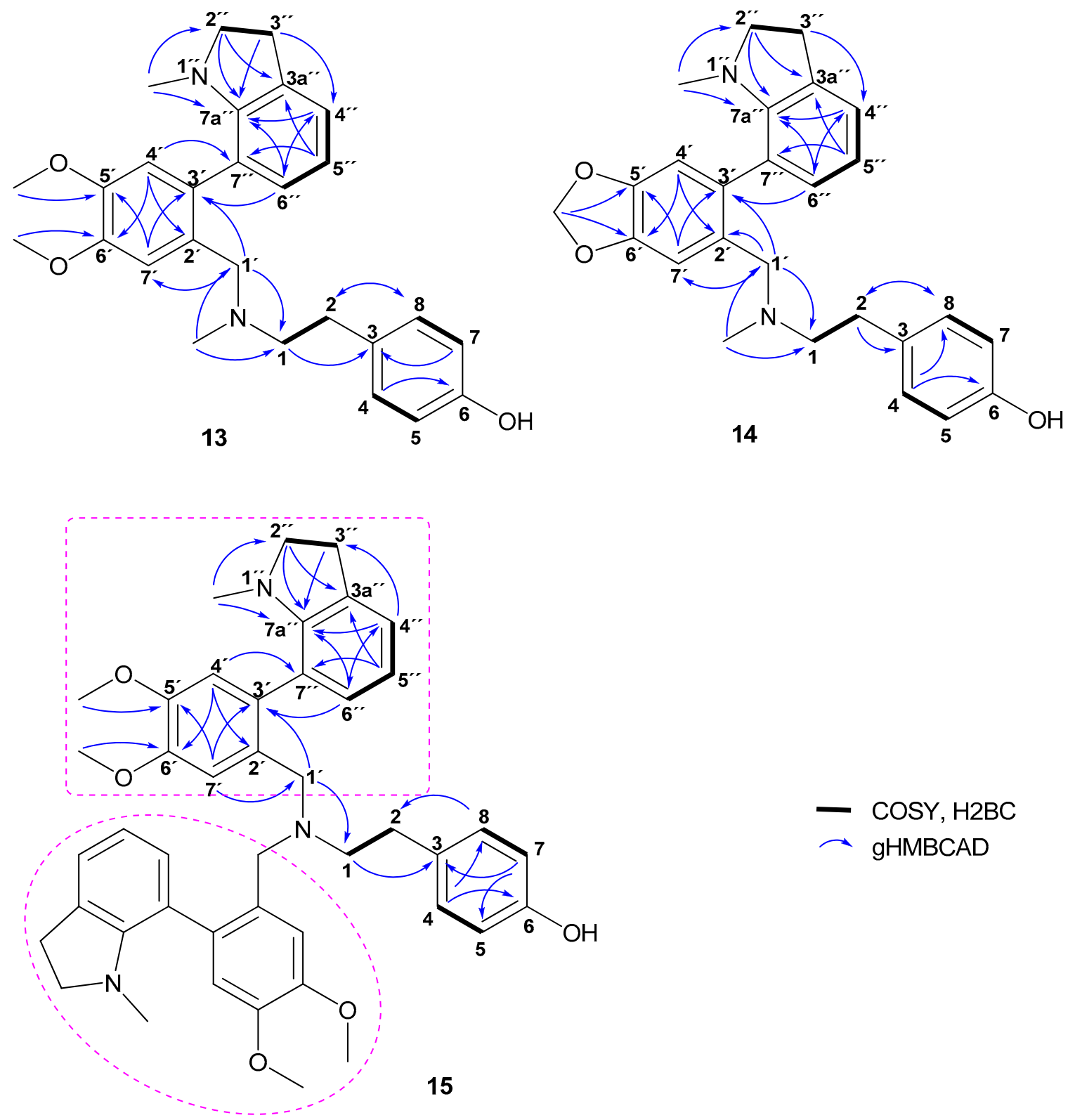

Figure 2. Key 2D NMR correlations of compounds 13-15. 
Table 1. ${ }^{1} \mathrm{H}$ NMR $(500 \mathrm{MHz})$ and ${ }^{13} \mathrm{C}$ NMR $(125.7 \mathrm{MHz})$ data for $\mathbf{1 3}-\mathbf{1 5}$ in $\mathrm{CDCl}_{3}$ ( $\delta$ in ppm and $J$ in $\left.\mathrm{Hz}\right)$.

\begin{tabular}{|c|c|c|c|c|c|c|}
\hline \multirow[b]{2}{*}{ Position } & \multicolumn{2}{|c|}{ Carltonine A (13) } & \multicolumn{2}{|c|}{ Carltonine B (14) } & \multicolumn{2}{|c|}{ Carltonine C (15) } \\
\hline & $\delta_{\mathrm{C}}$ & $\delta_{\mathrm{H}}$ & $\delta_{\mathrm{C}}$ & $\delta_{\mathrm{H}}$ & $\delta_{\mathrm{C}}$ & $\delta_{\mathrm{H}}$ \\
\hline 1 & 59.2 & $2.58-2.46, \mathrm{~m}$ & 59.3 & $2.56-2.45, \mathrm{~m}$ & $55.2 ; 55.4$ & 2.66-2.42, m \\
\hline 2 & 32.8 & $2.65, \mathrm{t}(7.4)$ & 32.7 & $2.66-2.58, \mathrm{~m}$ & $32.7 ; 32.8$ & $2.66-2.42, \mathrm{~m}$ \\
\hline 3 & 132.5 & & 132.2 & & 132.8 & \\
\hline 4 & 129.8 & $7.00-6.96, \mathrm{~m}$ & 129.7 & $7.00-6.94, \mathrm{~m}$ & 129.9 & $6.93-6.86, \mathrm{~m}$ \\
\hline 5 & 115.1 & $6.72-6.68, \mathrm{~m}$ & 115.2 & $6.75-6.72, \mathrm{~m}$ & 114.9 & $6.71-6.65, \mathrm{~m}$ \\
\hline 6 & 154.0 & & 153.9 & & 153.7 & \\
\hline 7 & 115.1 & $6.72-6.68, \mathrm{~m}$ & 115.2 & $6.75-6.72, \mathrm{~m}$ & 114.9 & $6.71-6.65, \mathrm{~m}$ \\
\hline 8 & 129.8 & $7.00-6.96, \mathrm{~m}$ & 129.7 & $7.00-6.94, \mathrm{~m}$ & 129.9 & $6.93-6.86, \mathrm{~m}$ \\
\hline $1^{\prime}$ & 58.5 & $\begin{array}{c}3.45, \mathrm{~d}(14.0) \\
3.29, \mathrm{~d} \text {, overlap }(14.0)\end{array}$ & 58.3 & $\begin{array}{l}3.46, \mathrm{~d}(13.2) \\
3.27, \mathrm{~d}(13.2)\end{array}$ & $55.1 ; 55.0$ & $\begin{array}{c}3.43, \mathrm{~d}(14.5) \\
3.29, \mathrm{~d}(14.5) \\
\quad 3.37, \mathrm{~s}\end{array}$ \\
\hline $2^{\prime}$ & 130.1 & & 130.6 & & $131.2 ; 131.0$ & \\
\hline $3^{\prime}$ & 132.1 & & 133.3 & & $131.9 ; 131.8$ & \\
\hline $4^{\prime}$ & 113.2 & $6.76, \mathrm{~s}$ & 110.2 & $6.75-6.72, \mathrm{~m}$ & $\begin{array}{l}113.23 ; \\
113.15\end{array}$ & $6.74, \mathrm{~s}$ \\
\hline $5^{\prime}$ & 146.9 & & 145.9 & & 146.7 & \\
\hline $6^{\prime}$ & 148.1 & & 147.0 & & 147.9 & \\
\hline $7^{\prime}$ & 111.1 & 7.10, s, overlap & 108.6 & 7.07, s, overlap & $110.6 ; 110.5$ & $\begin{array}{l}7.15, \mathrm{~s} \\
7.14, \mathrm{~s}\end{array}$ \\
\hline $2^{\prime \prime}$ & 57.1 & $\begin{array}{c}\text { 3.32, dt, overlap }(17.3,8.8) \\
3.20, \mathrm{dt}(17.3,8.8)\end{array}$ & 57.1 & $\begin{array}{l}3.35, \mathrm{dt}(17.5,8.7) \\
3.16, \mathrm{dt}(17.5,8.7)\end{array}$ & $57.1 ; 57.0$ & 3.27-3.17, m \\
\hline $3^{\prime \prime}$ & 28.6 & $2.98, \mathrm{t}(8.8)$ & 28.6 & $3.00-2.93, \mathrm{~m}$ & 28.6 & 2.99-2.91, m \\
\hline $3 a^{\prime \prime}$ & 131.2 & & 131.2 & & 131.1 & \\
\hline $4^{\prime \prime}$ & 123.3 & $7.09, \mathrm{dd}$, overlap $(7.4,1.0)$ & 123.4 & $7.08, \mathrm{~d}$, overlap $(7.4)$ & 123.3 & $7.07, \mathrm{~d}(7.4)$ \\
\hline $5^{\prime \prime}$ & 117.9 & $6.72, \mathrm{t}$, overlap $(7.4)$ & 118.1 & $6.70, \mathrm{t}$, overlap $(7.4)$ & $117.9 ; 117.8$ & $6.71-6.65, \mathrm{~m}$ \\
\hline $6^{\prime \prime}$ & 130.5 & $6.82, \mathrm{dd}(7.4,1.0)$ & 130.4 & $6.79, \mathrm{~d}(7.4)$ & $130.3 ; 130.4$ & $6.77, \mathrm{~d}(7.4)$ \\
\hline $7^{\prime \prime}$ & 123.0 & & 122.9 & & 122.8 & \\
\hline $7 a^{\prime \prime}$ & 150.4 & & 150.4 & & $150.3 ; 150.2$ & \\
\hline $\mathrm{N}-\mathrm{Me}$ & 42.3 & $2.20, \mathrm{~s}$ & 41.9 & $2.18, \mathrm{~s}$ & - & - \\
\hline $\mathrm{N} 1^{\prime \prime}-\mathrm{Me}$ & 38.6 & $2.21, \mathrm{~s}$ & 38.8 & $2.23, \mathrm{~s}$ & $38.51 ; 38.48$ & $\begin{array}{l}2.14, \mathrm{~s} \\
2.12, \mathrm{~s}\end{array}$ \\
\hline $5^{\prime}-\mathrm{OMe}$ & 55.8 or 55.9 & $3.34, \mathrm{~s}$ & - & - & 55.9 & $3.84, \mathrm{~s}$ \\
\hline $6^{\prime}-\mathrm{OMe}$ & 55.8 or 55.9 & $3.34, \mathrm{~s}$ & - & - & 55.6 & $\begin{array}{l}3.82, \mathrm{~s} \\
3.81, \mathrm{~s}\end{array}$ \\
\hline$-\mathrm{OCH}_{2} \mathrm{O}-$ & - & - & 101.0 & $\begin{array}{l}5.99, \mathrm{~s} \\
5.98, \mathrm{~s}\end{array}$ & - & - \\
\hline
\end{tabular}

\subsection{Biological Activity Determination of Isolated Alkaloids}

All the isolated compounds that had not been studied previously for their inhibition potential of cholinesterases, and which were obtained in sufficient amounts, were screened for their $h \mathrm{AChE} / h \mathrm{BuChE}$ inhibition potency using a modified spectrophotometric method of Ellman et al. [36]. Furthermore, $h \mathrm{AChE} / \mathrm{hBuChE}$-active AAs were also studied for their ability to inhibit POP enzyme. Galanthamine and eserine were used as positive controls in the $h \mathrm{AChE} / h \mathrm{BuChE}$ assays. Berberine was selected as a positive control when measuring POP inhibition. The results are summarized in Table 2. Moreover, the in vitro data are justified by docking studies proposing orientation of the top-ranked ligands within the $h \mathrm{BuChE}$ gorge.

The $h \mathrm{AChE} / h \mathrm{BuChE}$ inhibitory activity of the AAs was initially screened at a concentration of $100 \mu \mathrm{M}$. Compounds displaying inhibition ability $>50 \%$ against one or both cholinesterases at the screening concentration were selected for the determination of their $\mathrm{IC}_{50}$ values (Table 2).

In the $h \mathrm{AChE}$ assay, all studied AAs displayed marginal inhibition potency (Table 2). On the other hand, all newly isolated belladine-type alkaloids (13-15) demonstrated promising inhibition activity towards $h \mathrm{BuChE}$ (Table 2; Figure 3). Indeed, compounds $\mathbf{1 3}$ and $\mathbf{1 4}$ displayed $\mathrm{IC}_{50}$ values in the nanomolar range ( $h \mathrm{BuChE} \mathrm{IC} \mathrm{I}_{50}=910 \mathrm{nM}$ and $31 \mathrm{nM}$, for 13 and 14, respectively).

From the structural perspective, both AAs are endowed with the same core structure, differing only in the substitution at positions $C-5^{\prime}$ and $C-6^{\prime}$, respectively (Figure 2). The presence of a 1,3-dioxolane 
ring in $\mathbf{1 4}$ compared with its opened dimethoxybenzene analogue $\mathbf{1 3}$ is plausibly responsible for the almost 30 times drop in $h \mathrm{BuChE}$ inhibition activity. Both compounds showed a $h \mathrm{BuChE}$ selective inhibition pattern with outstanding selectivity index (SI) values higher than 100 (Table 2).

Table 2. In vitro results of $h \mathrm{AChE}, h \mathrm{BuChE}$ and POP inhibition of selected AAs isolated from Narcissus pseudonarcissus cv. Carlton.

\begin{tabular}{|c|c|c|c|c|c|c|}
\hline Compound & $\begin{array}{c}\text { \%Inhibition } \\
h \mathrm{AChE} \pm \mathrm{SD}^{\mathrm{a}}\end{array}$ & $\begin{array}{l}h \mathrm{AChE} \mathrm{IC}_{50} \\
\pm \mathrm{SD}(\mu \mathrm{M})^{\mathrm{b}}\end{array}$ & $\begin{array}{c}\% \text { inhibition } \\
h \mathrm{BuChE} \pm \mathrm{SD}^{\mathrm{a}}\end{array}$ & $\begin{array}{c}h \mathrm{BuChE} \mathrm{IC}_{50} \pm \\
\mathrm{SD}(\mu \mathrm{M})^{\mathrm{b}}\end{array}$ & $\begin{array}{c}\text { SI for } \\
h \mathrm{BuChE}^{\mathrm{c}}\end{array}$ & $\begin{array}{l}\text { POP IC } \text { IC }_{50} \pm \\
\text { SD }(\mu \mathrm{M})^{b}\end{array}$ \\
\hline Lycosinine B (1) & $28 \pm 1$ & $>100$ & $42 \pm 1$ & $>100$ & nc & $258 \pm 14$ \\
\hline Trispheridine (2) & $6 \pm 1$ & $>100$ & $13 \pm 1$ & $>100$ & nc & $\mathrm{nm}$ \\
\hline Carltonine A (13) & $2 \pm 0$ & $>100$ & $98 \pm 1$ & $0.91 \pm 0.02$ & $>110$ & $143 \pm 12$ \\
\hline Carltonine B (14) & $40 \pm 1$ & $>100$ & $99 \pm 1$ & $0.031 \pm 0.001$ & $>3226$ & $\mathrm{~nm}$ \\
\hline Carltonine C (15) & $9 \pm 0$ & $>100$ & $78 \pm 1$ & $14.8 \pm 1.1$ & $>7$ & $\mathrm{~nm}$ \\
\hline Eserine $^{\mathrm{d}}$ & $\mathrm{nm}$ & $0.063 \pm 0.005$ & $\mathrm{~nm}$ & $0.13 \pm 0.01$ & 0.48 & $\mathrm{~nm}$ \\
\hline Berberine $^{\mathrm{d}}$ & $\mathrm{nm}$ & $0.72 \pm 0.11$ & $\mathrm{~nm}$ & $31 \pm 4$ & 0.02 & $142 \pm 21$ \\
\hline
\end{tabular}

a Tested at $100 \mu \mathrm{M}$ compound concentration; ${ }^{\mathrm{b}}$ Compound concentration required to decrease enzyme activity by $50 \%$; the values are the mean values \pm standard deviations (SD) of three independent measurements, each performed in triplicate; ${ }^{c}$ Selectivity index (SI) for $h \mathrm{BuChE}$ is determined as ratio $h \mathrm{AChE} \mathrm{IC}_{50} / h \mathrm{BuChE} \mathrm{IC}_{50}$; ${ }^{\mathrm{d}} \mathrm{Reference}$ compound; nc stands for not calculated; nm stands for not measured.

Our group has previously isolated similar compounds from fresh bulbs of Nerine bowdenii: 6-O-demethylbelladine (13) and 4'-O-demethylbelladine (14) (Figure 3) [37]. However, neither of these two alkaloids are substituted at position $C-7^{\prime}$, and differ from each other by the absence of one methoxy group (Figure 3) [37]. 4'-O-demethylbelladine $\left(\mathrm{IC}_{50}=30.7 \pm 4.0 \mu \mathrm{M}\right)$ displayed slightly better in vitro inhibition activity of $h \mathrm{BuChE}$ compared with galanthamine $\left(\mathrm{IC}_{50}=42 \pm 1 \mu \mathrm{M}\right)$. On the other hand, the compounds isolated within this study are more than 30 to 100 more potent $h \mathrm{BuChE}$ inhibitors, yielding a new structural lead scaffold that may be pursued in AD research.<smiles>COc1ccc(CN(C)CCc2ccc(O)cc2)cc1OC</smiles>

6-O-Demethylbelladine<smiles>COc1cc(CN(C)CCc2ccc(O)cc2)c(-c2cccc3c2N(C)CC3)cc1OC</smiles><smiles>COc1ccc(CCN(C)Cc2ccc(OC)c(O)c2)cc1</smiles>

4'-O-Demethylbelladine<smiles>CN(CCc1ccc(O)cc1)Cc1cc2c(cc1-c1cccc3c1N(C)CC3)OCO2</smiles>

Figure 3. Structures of newly isolated (13 and 14) and recently reported belladine-type AAs 6-O-demethylbelladine and 4'-O-demethylbelladine [37].

Since some of the alkaloids were only isolated on a small scale, only two (1 and 13) were able to be tested for POP inhibition. Alkaloid $\mathbf{1 3}$ demonstrated POP inhibition in the same range as berberine (Table 2) [38]. 
The biological profiles of the other AAs (Figure 1) have already been determined within previous studies on Amaryllidaceae plants [21,39-41].

\subsection{Docking Study of Carltonine A (13) and Carltonine B (14)}

To reveal fundamental interactions for $\mathbf{1 3}$ and $\mathbf{1 4}$ within the $h \mathrm{BuChE}$ active site (PDB ID: 4BDS) [42], molecular docking studies were carried out, enabling better insight into the structural requirements for inhibition. Since both $\mathbf{1 3}$ and $\mathbf{1 4}$ are tertiary amines, which are protonated at physiological $\mathrm{pH}$, they behave as pseudo-enantiomers. In this study, we attempted to predict more bioactive conformers of 13 and 14 based on their energy score and their topology within $h \mathrm{BChE}$. To gain a more in-depth outlook into the overall ligand-enzyme complex, we are also displaying several comparative structure overlay between $(R)-\mathbf{1 3}-(R)-\mathbf{1 4}$ (Figure S4A), (S)-13-(R)-13 (Figure S4B), (S)-13-(S)-14 (Figure S4C), and (S)-14-(R)-14 (Figure S4D) pseudo-enantiomers (see Supplementary Material).

Carltonine A (13) with a central amino moiety in $(R)$ (Figure 4A,B) and $(S)$ (Figure 4C,D) conformations displayed completely different binding modes, even though their estimated energetic balances were equipotent $(-10.6 \mathrm{kcal} / \mathrm{mol}$ for both). For the ( $R)-\mathbf{1 3}$ pseudo-enantiomer- $h \mathrm{BuChE}$ complex (Figure 5A,B), the $N$-methylindoline moiety occupies the vicinity of the catalytic triad with a T-shaped $\pi$ - $\pi$ interaction close to Phe329 (5.0 $\AA$, distance measured from ring-to-ring center). Trp82 faces the dimethoxybenzene ring by displacing $\pi-\pi$ interaction, whereas the phenolic appendage is left somewhat vacant. In the (S)-13 pseudo-enantiomer- $h \mathrm{BuChE}$ complex (Figure 4C,D), the $N$-methylindoline moiety is engaged in parallel $\pi-\pi$ stacking with $\operatorname{Trp} 82(3.7 \AA)$. Contrary to the vacant occupancy of the phenolic appendage in the (R)-13 pseudo-enantiomer, in the case of the (S)-13 pseudo-enantiomer, Phe329 (4.9 $\AA$ ) and Trp231 (5.5 $\AA$ ) anchor this moiety. The dimethoxybenzene ring is stabilized by $\pi$-anion contact to Asp70.

The top-ranked docking poses for $(R)-\mathbf{1 4}$ and (S)-14 pseudo-enantiomers in $h \mathrm{BuChE}$ active site are depicted in Figure 5A-D, respectively. In this case, binding energies differ favoring the $(R)-\mathbf{1 4}$ pseudo-enantiomer $(-11.6 \mathrm{kcal} / \mathrm{mol})$ over the $(S)-\mathbf{1 4}$ one $(-10.9 \mathrm{kcal} / \mathrm{mol})$. Similarly to the $(R)-\mathbf{1 3}$ pseudo-enantiomer- $h \mathrm{BuChE}$ complex, $N$-methylindoline is stabilized by T-shaped $\pi-\pi$ interaction with Phe329 (5.0 $\AA$ ) and by cation- $\pi$ formation with the central nitrogen atom of $(R)-\mathbf{1 4}$ (Figure 5A,B). The protonated amino-group of $(R)-\mathbf{1 4}$ orchestrates the ligand-enzyme contact by other cation- $\pi$ interactions with Tyr332 (5.3 $)$ and Trp82 (4.5 $)$. The latter amino acid residue is in close vicinity to $2 H-1,3$-benzodioxole displaying T-shaped $\pi-\pi$ stacking $(4.8 \AA)$, and additionally to the phenolic moiety of the ligand via parallel $\pi-\pi$ stacking (3.8 $\AA$ ). Likewise, the same applies for the (S)-14 pseudo-enantiomer in $h \mathrm{BuChE}$ (Figure 5C,D) when observing the central protonated amine of the ligand, i.e., cation- $\pi$ contact with Tyr332 (5.5 $\AA$ ) and Phe329 (5.4 $\AA$ ), but not with Trp82. In this case, Trp82 revealed only an apparently parallel $\pi-\pi$ interaction with the $N$-methylindoline moiety $(3.7 \AA)$.

Taken together from all the in silico observations above, it can be deduced that the higher inhibition potency of $\mathbf{1 4}$ over $\mathbf{1 3}$ might be attributed to the presence of the $2 \mathrm{H}-1,3$-benzodioxole moiety for its "extended" aromatic properties that, especially in the $(R)-\mathbf{1 4}$ pseudo-enantiomer, broaden the range of hydrophobic interactions between the ligand and enzyme (Table 3). 


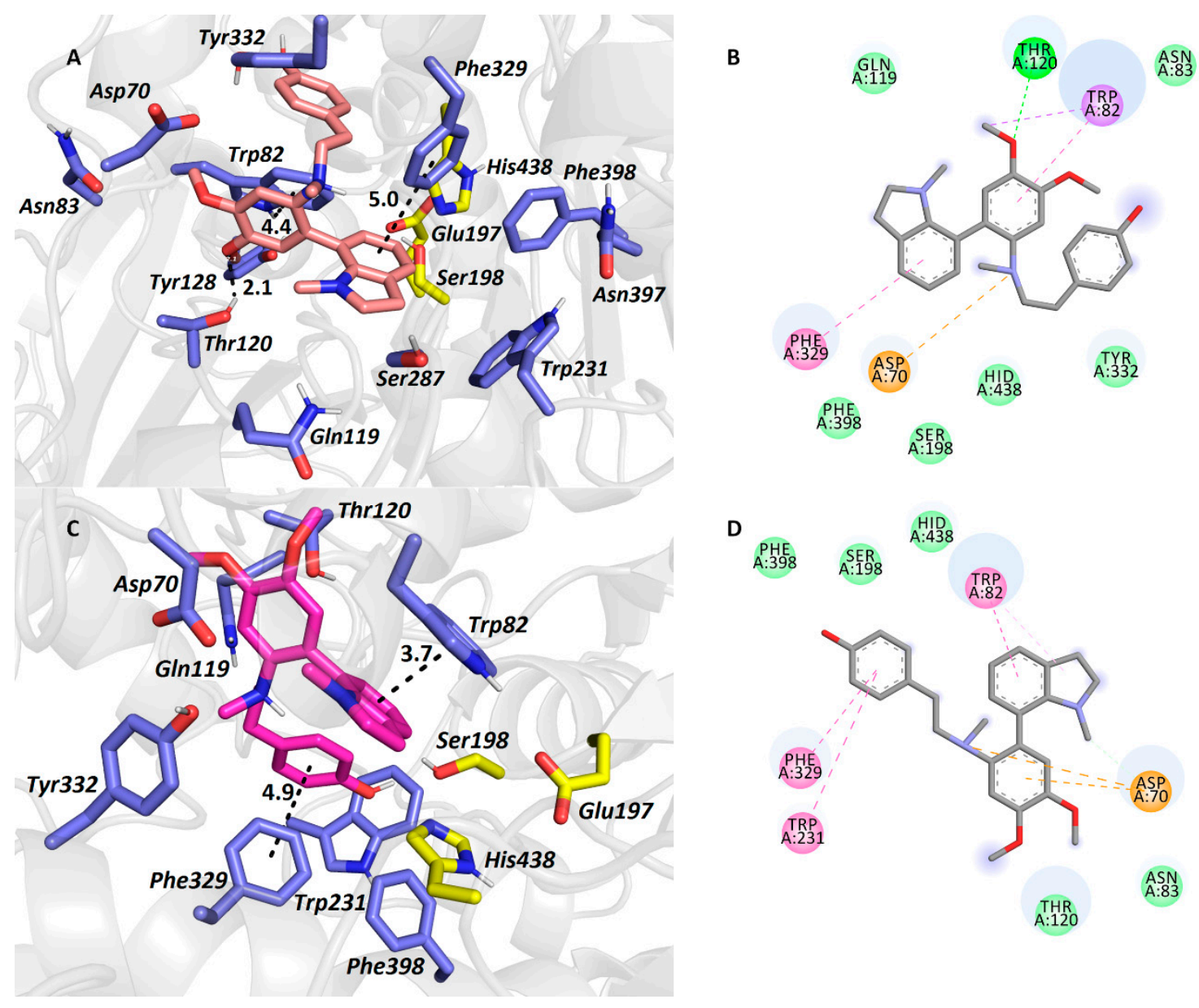

Figure 4. The $h \mathrm{BuChE}$ active site in complex with (R)-13 (in salmon, A,B) and (S)-13 (in purple, C,D) pseudo-enantiomers. All the amino acids exhibiting in the vicinity of the ligands up-to $6.0 \AA$ are rendered. Hydrogen atoms of amino acids are omitted for clarity. Catalytic triad residues are shown in yellow, and amino acid residues in blue (A,C). In 2D diagrams (B,D), crucial amino acid residues are displayed in different colours depending on the nature of the interaction (e.g., purple for $\pi-\pi$, orange for anion- $\pi$, dark green for van der Waals contact, and light green for conventional hydrogen bond).

Table 3. The best obtained calculated binding energies with Autodock Vina software for the carltonine derivatives under the in silico study within $h \mathrm{BuChE}$ enzyme.

\begin{tabular}{cc}
\hline Carltonine Enantiomer & Calculated Binding Energy (kcal/mol) \\
\hline$(R)-\mathbf{1 3}$ & -10.6 \\
$(S)-\mathbf{1 3}$ & -10.6 \\
$(R)-\mathbf{1 4}$ & -11.6 \\
$(S)-\mathbf{1 4}$ & -10.9 \\
\hline
\end{tabular}




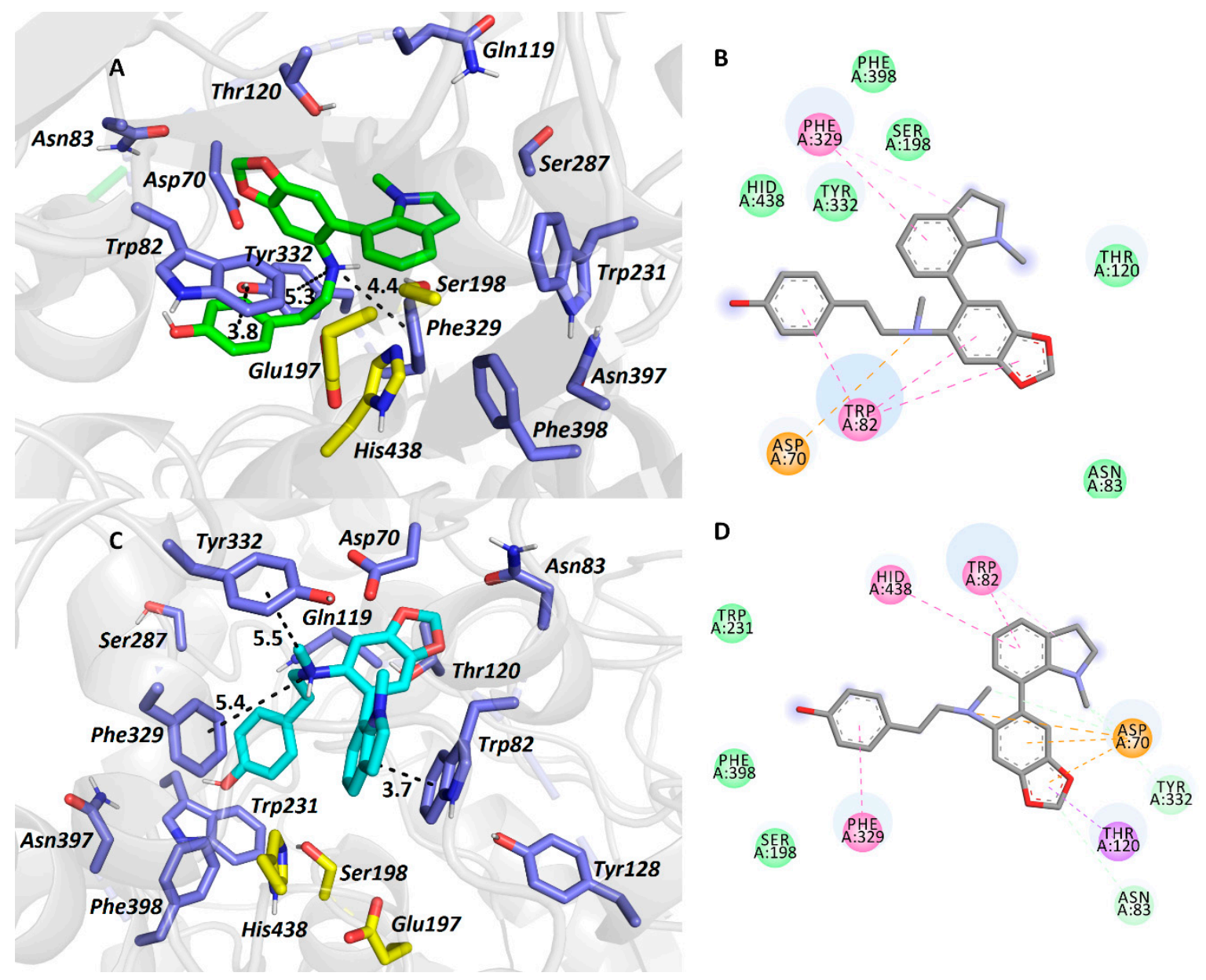

Figure 5. $h \mathrm{BuChE}$ active site in complex with $(R)$-14 (in green, $\mathbf{A}, \mathbf{B})$ and $(S)$-14 (in light-blue, $\mathbf{C}, \mathbf{D}$ ) pseudo-enantiomers. All the amino acids exhibiting in the vicinity of the ligands up-to $6.0 \AA$ are rendered. Hydrogen atoms of amino acids are omitted for clarity. Catalytic triad residues are shown in yellow and amino acid residues in blue (A,C). In 2D diagrams (B,D), crucial amino acid residues are displayed in different colours depending on the nature of the interaction (e.g., purple for $\pi-\pi$, orange for anion- $\pi$, dark green for van der Waals contact, light green for conventional hydrogen bond).

\section{Experimental}

\subsection{General Experimental Procedures}

All solvents were treated using standard techniques before use. All reagents and catalysts were purchased from Sigma Aldrich, Czech Republic and used without purification. The NMR spectra were obtained in $\mathrm{CDCl}_{3}$ and $\mathrm{CD}_{3} \mathrm{OD}$ at ambient temperature on a VNMR S500 (Varian, Palo Alto, CA, USA) spectrometer operating at $500 \mathrm{MHz}$ for ${ }^{1} \mathrm{H}$ and $125.7 \mathrm{MHz}$ for ${ }^{13} \mathrm{C}$. Chemical shifts were recorded as $\delta$ values in parts per million (ppm) and were indirectly referenced to tetramethylsilane (TMS) via the solvent signal $\left(\mathrm{CDCl}_{3}-7.26 \mathrm{ppm}\right.$ for ${ }^{1} \mathrm{H}$ and $77.0 \mathrm{ppm}$ for ${ }^{13} \mathrm{C} ; \mathrm{CD}_{3} \mathrm{OD}-3.30 \mathrm{ppm}$ for ${ }^{1} \mathrm{H}$ and $49.0 \mathrm{ppm}$ for ${ }^{13} \mathrm{C}$ ). Coupling constants $(J)$ are given in $\mathrm{Hz}$. For unambiguous assignment of ${ }^{1} \mathrm{H}$ and ${ }^{13} \mathrm{C}$ signals, 2D NMR experiments, namely gCOSY, gHSQC, gHMBC and NOESY, were measured using standard parameter settings and standard pulse programs provided by the producer of the spectrometer. ESI-HRMS were obtained with a Waters Synapt G2-Si hybrid mass analyzer of a quadrupole-time-of-flight (Q-TOF) type, coupled to a Waters Acquity I-Class UHPLC system. The EI-MS were obtained on an Agilent 7890A GC 5975 inert MSD operating in EI mode at $70 \mathrm{eV}$ (Agilent Technologies, Santa Clara, CA, USA). A DB-5 column $(30 \mathrm{~m} \times 0.25 \mathrm{~mm} \times 0.25 \mu \mathrm{m}$, Agilent Technologies, USA) was used with a temperature program: $100-180{ }^{\circ} \mathrm{C}$ at $15^{\circ} \mathrm{C} / \mathrm{min}, 1 \mathrm{~min}$ hold at 
$180^{\circ} \mathrm{C}$, and $180-300^{\circ} \mathrm{C}$ at $5^{\circ} \mathrm{C} / \mathrm{min}$ and $5 \mathrm{~min}$ hold at $300^{\circ} \mathrm{C}$; and detection range $\mathrm{m} / \mathrm{z} 40-600$. The injector temperature was $280^{\circ} \mathrm{C}$. The flow-rate of carrier gas (helium) was $0.8 \mathrm{~mL} / \mathrm{min}$. A split ratio of 1:15 was used. TLC was carried out on Merck precoated silica gel 60 F254 plates. Compounds on the plate were observed under UV light (254 and $366 \mathrm{~nm}$ ) and visualized by spraying with Dragendorff's reagent.

\subsection{Plant Material}

The fresh bulbs of Narcissus pseudonarcissus cv. Carlton were obtained from the herbal dealer Lukon Glads (Sadská, Czech Republic). Botanical identification was performed by Prof. L. Opletal. A voucher specimen is deposited in the Herbarium of the Faculty of Pharmacy in Hradec Králové under number: CUFPH-16130/AL-654.

\subsection{Extraction and Isolation of Alkaloids}

Fresh bulbs (30 kg) were minced and completely extracted with ethanol $(\mathrm{EtOH})(96 \%, v / v, 3 \times)$ by boiling for 30 min under reflux; the combined extract was filtered and evaporated to dryness under reduced pressure. The crude extract $(485 \mathrm{~g})$ was acidified to $\mathrm{pH} 1-2$ with $2 \%$ hydrochloric acid $(\mathrm{HCl}$; $1 \mathrm{~L}$ ) and the volume of the suspension was made up to $5 \mathrm{~L}$ with water. The suspension was filtered; the filtrate was defatted by diethyl ether $\left(\mathrm{Et}_{2} \mathrm{O}, 3 \times 1.5 \mathrm{~L}\right)$, alkalized to $\mathrm{pH} 9-10$ with a $10 \%$ solution of sodium carbonate $\left(\mathrm{Na}_{2} \mathrm{CO}_{3}\right)$ and extracted with ethyl acetate $($ EtOAc; $3 \times 1.5 \mathrm{~L})$. The organic layer was evaporated to give $245 \mathrm{~g}$ of dark brown fluid residue. The alkaloid summary extract was again dissolved in $2 \% \mathrm{HCl}(1000 \mathrm{~mL})$, washed with $\mathrm{Et}_{2} \mathrm{O}(3 \times 300 \mathrm{~mL})$ and alkalized to $\mathrm{pH} 9-10$ with $10 \%$ $\mathrm{Na}_{2} \mathrm{CO}_{3}$. The water layer was extracted with $\mathrm{Et}_{2} \mathrm{O}(4 \times 350 \mathrm{~mL})$ and chloroform $\left(\mathrm{CHCl}_{3} ; 4 \times 350 \mathrm{~mL}\right)$. Both Dragendorff positive parts were evaporated and pooled. A concentrated alkaloid extract (187 g) in the form of brown syrup was obtained.

The alkaloid extract was further fractionated by column chromatography on aluminum oxide $\left(\mathrm{Al}_{2} \mathrm{O}_{3} ; 5800 \mathrm{~g}\right)$, eluting with light petrol gradually enriched with $\mathrm{CHCl}_{3}(1: 1,2: 3,1: 4$; each $5000 \mathrm{~mL})$, followed by $\mathrm{CHCl}_{3}(3000 \mathrm{~mL})$ and finally by $\mathrm{CHCl}_{3}$ enriched with EtOH $(99: 1,49: 1,97: 3,12: 1,1: 1$; 0:100 each $3000 \mathrm{~mL}$ ). Fractions were collected in amounts of $1000 \mathrm{~mL}$ and monitored by TLC. Finally, 423 fractions were collected, combined into 25 fractions, and analyzed by GC-MS. Fractions with similar profile were pooled together to give nine final fractions (I-IX).

Fraction I (650 mg) was recrystallized from an ethanol/chloroform mixture (1:1, $100 \mathrm{~mL})$ to give lycosinine B (1, $48 \mathrm{mg})$. Preparative TLC of the mother liquor (To: $\mathrm{cHx}$ : $\left.\mathrm{t}_{2} \mathrm{NH}, 60: 40: 5,1 \times\right)$ led to the isolation of trispheridine $(2,5 \mathrm{mg})$. Repeated preparative TLC of the mother liquor gave 3,4-anhydrogalanthamine (3, $5 \mathrm{mg})$.

Fraction II (500 mg) was fractionated by preparative TLC (cHx: $\left.\mathrm{Me}_{2} \mathrm{CO}: \mathrm{NH}_{3} ; 30: 60: 1 ; 1 \times\right)$. Three subfractions were obtained (IIa-c). Repeated preparative TLC of subfraction IIb (cHx: $\mathrm{Me}_{2} \mathrm{CO}$ : $\left.\mathrm{NH}_{3}, 30: 60: 1 ; 2 \times\right)$ led to the isolation of oduline $(4 ; 11 \mathrm{mg})$. Additional preparative TLC of subfraction IIc gave masonine (5; $44 \mathrm{mg})$.

Fraction III (16.3 g) was crystallized and recrystallized from EtOH and, finally, $6.39 \mathrm{~g}$ of galanthamine (6) was obtained.

Fraction IV (1.7 g) was further chromatographed by preparative TLC (To: $c H x: \mathrm{Et}_{2} \mathrm{NH}, 10: 10: 2$, $2 \times)$ to obtain subfractions Iva-b. Repeated preparative TLC of IVa $\left(320 \mathrm{mg} ; \mathrm{cHx} \mathrm{Et}_{2} \mathrm{NH}, 9: 1 ; 2 \times\right)$ led to the isolation of galanthine $(7 ; 120 \mathrm{mg})$.

Fraction V (3.05 g) was crystallized and recrystallized three times from EtOH to give lycorenine (9; $981 \mathrm{mg})$.

Fraction VI (950 mg) was subjected to preparative TLC (To: $\left.\mathrm{cHx}_{\mathrm{E}} \mathrm{Et}_{2} \mathrm{NH}, 50: 50: 5 ; 2 \times\right)$ to obtain four subfractions VIa-d. Subfraction VIa $\left(120 \mathrm{mg}\right.$ ) was treated by preparative TLC (cHx: $\mathrm{Me}_{2} \mathrm{CO}: \mathrm{NH}_{3}$, 20:80:1; 2 x) to give lycoramine $(\mathbf{9} ; 20 \mathrm{mg})$. Subfraction VIb $(150 \mathrm{mg})$ was subjected to preparative TLC (To: $\mathrm{cHx}$ : $\mathrm{Et}_{2} \mathrm{NH} ; 40: 60: 5 ; 2 \times$ ), crystallized from $\mathrm{EtOH}$, and $45 \mathrm{mg}$ of homolycorine (10) was obtained. 
Fraction VII (25 g) was dissolved in hot EtOH and crystallized. Crude haemanthamine (11; $14.5 \mathrm{~g}$ ) was obtained. This was repetitively $(3 \times)$ recrystallized from hot $\mathrm{EtOH}$ to give $10.5 \mathrm{~g}$ of pure haemanthamine.

Repetitive preparative TLC (EtOAc: $\mathrm{cHx}$ : $\mathrm{Et}_{2} \mathrm{NH} ; 70: 20: 10 ; 3 \times$ ) of fraction VIII (3.25 g) led to the isolation of five subfractions (VIIIa-e). Subfraction VIIIa (545 mg) was subjected to preparative TLC $\left(\mathrm{CH}_{3} \mathrm{CN}: \mathrm{MeOH}: \mathrm{NH}_{3} ; 70: 20: 0.3 ; 2 \times\right)$ to give vitattine (12; $\left.150 \mathrm{mg}\right)$. Subfraction VIIIc (550 mg) was chromatographed by preparative TLC (EtOAc: $\mathrm{cHx}: \mathrm{NH}_{3} ; 40: 24: 0.6 ; 2 \times$ ) to give carltonine A (13; $70 \mathrm{mg}$ ) and subfraction VIIIc/1. Subfraction VIIIc/1 $(80 \mathrm{mg})$ was subjected to preparative TLC (EtOAc: cHx: $\left.\mathrm{NH}_{3} ; 40: 24: 0.6 ; 1 \times\right)$ and carltonine B $(\mathbf{1 4} ; 6 \mathrm{mg})$ was obtained. Subfraction VIIId $(75 \mathrm{mg})$ was further treated by preparative TLC (EtOAc: $\left.\mathrm{Chx}: \mathrm{NH}_{3} ; 40: 24: 0.6 ; 2 \times\right)$ to yield carltonine $\mathrm{C}(\mathbf{1 5} ; 7 \mathrm{mg})$.

Fraction IX (1.65 g) was subjected to preparative TLC (To: $\left.\mathrm{Me}_{2} \mathrm{CO}: \mathrm{MeOH}: \mathrm{NH}_{3} ; 50: 60: 10: 1 ; 1 \times\right)$ to give two subfractions IXa-b. Subfraction IXa $(320 \mathrm{mg})$ was recrystallized from hot EtOH and separated by preparative TLC (To: $\mathrm{Me}_{2} \mathrm{CO}: \mathrm{NH}_{3} ; 40: 60: 1 ; 2 \times$ ) to give 9-O-demethylhomolycorine $(\mathbf{1 6} ; 35 \mathrm{mg}$ ).

Carltonine $A$ (13): pale yellow oil; for ${ }^{1} \mathrm{H}$ and ${ }^{13} \mathrm{C}$ NMR data see Table 1; HRMS $m / z 433.2488$ $[\mathrm{M}+\mathrm{H}]^{+}$(calculated for $\mathrm{C}_{27} \mathrm{H}_{33} \mathrm{~N}_{2} \mathrm{O}_{3}{ }^{+}, 433.2486$ ).

Carltonine $B$ (14): pale yellow oil; for ${ }^{1} \mathrm{H}$ and ${ }^{13} \mathrm{C}$ NMR data see Table 1; HRMS $m / z 417.2172$ $[\mathrm{M}+\mathrm{H}]^{+}$(calculated for $\mathrm{C}_{26} \mathrm{H}_{29} \mathrm{~N}_{2} \mathrm{O}_{3}{ }^{+}, 417.2173$ ).

Carltonine $C$ (15): yellowish amorphous solid; for ${ }^{1} \mathrm{H}$ and ${ }^{13} \mathrm{C}$ NMR data see Table 1 ; HRMS $\mathrm{m} / \mathrm{z}$ $700.3743[\mathrm{M}+\mathrm{H}]^{+}$(calculated for $\mathrm{C}_{44} \mathrm{H}_{50} \mathrm{~N}_{3} \mathrm{O}_{5}{ }^{+}, 700.3745$ ).

\subsection{Biological Assays}

\subsection{1. hAChE and hBuChE Inhibition Assay}

The $h \mathrm{AChE}$ and $h \mathrm{BuChE}$ activities were determined using a modified method of Ellman, as described $[36,43,44]$. Briefly, $h \mathrm{AChE}$ and $h \mathrm{BuChE}$ activities were determined using a modified method of Ellman, with acetylthiocholine iodide (ATChI) and butyrylthiocholine iodide (BuTChI) as substrates, respectively. Briefly, $8.3 \mu \mathrm{L}$ of either blood cell lysate or plasma dilutions (at least six different concentrations), $283 \mu \mathrm{L}$ of $5 \mathrm{mM} 5,5^{\prime}$-dithiobis-2-nitrobenzoic acid (DTNB) and $8.3 \mu \mathrm{L}$ of the sample dilution in dimethyl sulfoxide (DMSO) $(40 \mathrm{mM}, 10 \mathrm{mM}, 4 \mathrm{mM}, 1 \mathrm{mM}, 0.4 \mathrm{mM}$, and $0 \mathrm{mM}$ ) were added to the semi-micro cuvette. The reaction was initiated by addition of $33.3 \mu \mathrm{L} 10 \mathrm{mM}$ substrate (ATChI or BuTChI). The final proportion of DTNB and substrate was 1:1. The increase of absorbance $(\triangle \mathrm{A})$ at $436 \mathrm{~nm}$ for $\mathrm{AChE}$ and $412 \mathrm{~nm}$ for BuChE was measured for $1 \mathrm{~min}$ at $37^{\circ} \mathrm{C}$ using a spectrophotometer (Synergy ${ }^{\mathrm{TM}}$ HT Multi-Detection Microplate Reader). Each measurement was repeated six times for every concentration of enzyme preparation. The $\%$ inhibition was calculated according to the following formula:

$$
\% I=100-\left(100 \times \frac{\Delta A_{B l}}{\Delta A_{S a}}\right),
$$

where $\Delta A_{B l}$ is the increase of absorbance of the blank sample and $\Delta A_{S a}$ is the increase of absorbance of the measured sample. Inhibition potency of the tested compounds was expressed as an $\mathrm{IC}_{50}$ value (concentration of inhibitor, which causes 50\% cholinesterase inhibition).

\subsubsection{POP Inhibition Assay}

POP (EC 3.4.21.26) was dissolved in phosphate-buffered saline (PBS; $0.01 \mathrm{M} \mathrm{Na} / \mathrm{K}$ phosphate buffer, $\mathrm{pH} 7.4$, containing $137 \mathrm{mM} \mathrm{NaCl}$ and $2.7 \mathrm{mM} \mathrm{KCl}$ ); the specific activity of the enzyme was $0.2 \mathrm{U} / \mathrm{mL}$. The assay was performed in standard polystyrene 96-well microplates with a flat and clear bottom. Stock solutions of tested compounds were prepared in DMSO $(10 \mathrm{mM})$. Dilutions $\left(10^{-3}\right.$ to $\left.10^{-7} \mathrm{M}\right)$ were prepared from the stock solution with deionized $\mathrm{H}_{2} \mathrm{O}$; the control was performed with the same DMSO concentration. POP substrate, (Z)-Gly-Pro-p-nitroanilide, was dissolved in 50\% 1,4-dioxane $(5 \mathrm{mM})$. For each reaction, PBS $(170 \mu \mathrm{L})$, tested compound $(5 \mu \mathrm{L})$, and POP $(5 \mu \mathrm{L})$ were incubated 
for $5 \mathrm{~min}$ at $37^{\circ} \mathrm{C}$. Then, substrate $(20 \mu \mathrm{L})$ was added, and the microplate was incubated for $30 \mathrm{~min}$ at $37^{\circ} \mathrm{C}$. The formation of p-nitroanilide, directly proportional to the POP activity, was measured spectrophotometrically at $405 \mathrm{~nm}$ using a microplate ELISA reader (multimode microplate reader Synergy 2, BioTek Instruments, Winooski, VT, USA). The inhibition potency of tested compounds was calculated by nonlinear regression analysis and was expressed as an $\mathrm{IC}_{50}$ value (concentration of inhibitor which causes 50\% POP inhibition). All calculations were performed using GraphPad Prism software version 7.03 for Windows (GraphPad Software Inc., San Diego, California, USA) [44].

\subsubsection{Molecular Modelling Studies}

Two structures of $h \mathrm{AChE}$ and $h \mathrm{BuChE}$ were gained from RCSB Protein Data Bank-PDB ID: 4EY6 (crystal structure of $h \mathrm{AChE}$ ) and 4BDS (crystal structure of $h \mathrm{BuChE}$ ) [42,45]. All receptor structures were prepared by DockPrep function of UCSF Chimera (v. 1.4) and converted to pdbqt-files by AutodockTools (v. 1.5.6) [46,47]. Flexible residues selection was based on previous experience with either $h \mathrm{AChE}, h \mathrm{BuChE}$ or the spherical region around the binding cavity [48-50]. Three-dimensional structures of ligands were built by Open Babel (v. 2.3.1), minimized by Avogadro (v 1.1.0) and converted to pdbqt-file format by AutodockTools [51]. The docking calculations were made by Autodock Vina (v. 1.1.2) with the exhaustiveness of 8 [52]. Calculation was repeated 20 times for each ligand and receptor and the best-scored result was selected for manual inspection. The visualization of enzyme-ligand interactions was prepared using The PyMOL Molecular Graphics System (Version 2.0, Schrödinger, LLC, Mannheim, Germany). 2D diagrams were created with Dassault Systèmes BIOVIA, Discovery Studio Visualizer (v 17.2.0.16349, Dassault Systèmes, 2016, San Diego, CA, USA).

\section{Conclusions}

The phytochemical study of the alkaloidal extract of Narcissus pseudonarcissus cv. Carlton resulted in the isolation of thirteen previously described AAs, and three new AAs of belladine-type, named carltonine A-C (13-15). Their structures were elucidated using a combination of NMR and MS analysis. Compounds isolated in sufficient quantity and not previously tested for their biological activities in relation to AD, were screened for their potential to inhibit $h \mathrm{AChE}, h \mathrm{BuChE}$ and POP. Significant and selective $h \mathrm{BuChE}$ inhibitory activity was demonstrated by the newly described alkaloids carltonine A (13) and carltonine B (14) with $\mathrm{IC}_{50}$ values of $0.91 \pm 0.02 \mu \mathrm{M}$ and $0.031 \pm 0.001$ $\mu \mathrm{M}$, respectively. The in vitro results were justified by computational studies predicting plausible binding modes of compounds $\mathbf{1 3}$ and $\mathbf{1 4}$ in the active site of $h \mathrm{BuChE}$. The new compounds exerted an interesting biological profile deserving further lead-optimization. The next step will be the development of an appropriate synthetic route leading to carltonine derivatives with follow-up preparation of semi-synthetic derivatives.

Supplementary Materials: The following are available online at http://www.mdpi.com/2218-273X/10/5/800/s1, Figure S1-1: ESI-HRMS spectrum of carltonine A (13); Figure S1-2: ${ }^{1} \mathrm{H}$ NMR spectrum of carltonine A (13) in $\mathrm{CDCl}_{3}$; Figure S1-3: ${ }^{13} \mathrm{C}$ NMR spectrum of carltonine A (13) in $\mathrm{CDCl}_{3}$; Figure S1-4: gCOSY spectrum of carltonine $\mathrm{A}$ (13) in $\mathrm{CDCl}_{3}$; Figure S1-5: gHSQC spectrum of carltonine A (13) in $\mathrm{CDCl}_{3}$; Figure S1-6: gHMBCAD spectrum of carltonine $\mathrm{A}$ (13) in $\mathrm{CDCl}_{3}$; Figure S1-7: gH2BC spectrum of carltonine A (13) in $\mathrm{CDCl}_{3}$; Figure S2-1: ESI-HRMS spectrum of carltonine B (14); Figure S2-2: ${ }^{1} \mathrm{H}$ NMR spectrum of carltonine B (14) in $\mathrm{CDCl}_{3}$; Figure S2-3: ${ }^{13} \mathrm{C}$ NMR spectrum of carltonine $\mathrm{B}(\mathbf{1 4})$ in $\mathrm{CDCl}_{3}$; Figure S2-4: gCOSY spectrum of carltonine $\mathrm{B}(\mathbf{1 4})$ in $\mathrm{CDCl}_{3} ;$ Figure S2-5: gHSQC spectrum of carltonine B (14) in $\mathrm{CDCl}_{3}$; Figure S2-6: gHMBCAD spectrum of carltonine $\mathrm{B}(\mathbf{1 4})$ in $\mathrm{CDCl}_{3}$; Figure S2-7: gH2BC spectrum of carltonine $\mathrm{B}(\mathbf{1 4})$ in $\mathrm{CDCl}_{3}$; Figure S3-1: ESI-HRMS spectrum of carltonine C (15); Figure S3-2: ${ }^{1} \mathrm{H}$ NMR spectrum of carltonine $\mathrm{C}(\mathbf{1 5})$ in $\mathrm{CDCl}_{3}$; Figure S3-3: ${ }^{13} \mathrm{C}$ NMR spectrum of carltonine $\mathrm{C}(\mathbf{1 5})$ in $\mathrm{CDCl}_{3}$; Figure S3-4: gCOSY spectrum of carltonine $\mathrm{C}$ (15) in $\mathrm{CDCl}_{3}$; Figure S3-5: gHSQC spectrum of carltonine $\mathrm{C}(\mathbf{1 5})$ in $\mathrm{CDCl}_{3}$; Figure S3-6: gHMBCAD spectrum of carltonine $\mathrm{C}(\mathbf{1 5})$ in $\mathrm{CDCl}_{3}$; Figure S3-7: gH2BC spectrum of carltonine $\mathrm{C}(\mathbf{1 5})$ in $\mathrm{CDCl}_{3}$; Figure S3-8: ${ }^{1} \mathrm{H}$ NMR spectrum of carltonine $\mathrm{C}(\mathbf{1 5})$ in $\mathrm{CDCl}_{3}$ at $50{ }^{\circ} \mathrm{C}$; Figure S3-9: ${ }^{13} \mathrm{C}$ NMR spectrum of carltonine C (15) in $\mathrm{CDCl}_{3}$ at $50^{\circ} \mathrm{C}$; Figure S4: Overlapped pseudo-enantiomers in the $h \mathrm{BuChE}$ active site and their topology difference. 
Author Contributions: A.A.M., M.Š. contributed to the isolation of Amaryllidaceae alkaloids. J.M., J.K. (Jiří Kuneš), L.N. and M.Š. contributed to the identification of isolated alkaloids (such as MS, NMR). D.H., J.J. and M.H. were involved with the measurement of various biological activities of all isolated compounds. J.K. (Jan Korábečný), T.K. carried out the docking studies. L.C. and J.K. (Jan Korábečný) designed the study, supervised the laboratory work and contributed to critical reading of the manuscript. All authors have read and agreed to the published version of the manuscript.

Funding: This project was supported by Charles University grants (GA UK no. 178518, SVV UK 260 412, 260 401; Progres/UK Q40 and Q42), by MH CZ-DRO (University Hospital Hradec Kralove, no. 00179906), by the Czech Science Foundation (project no. 20-29633J), by the Long-term Development Plan (Faculty of Military Health Sciences), and by EFSA-CDN (no. CZ.02.1.01/0.0/0.0/16_019/0000841) co-funded by ERDF and by MICU (grant no. SAF2016-76693-R to A.M.). Computational resources were provided by CESNET LM2015042 and the CERIT Scientific Cloud LM2015085, provided under the program “Projects of Large Research, Development, and Innovations Infrastructures".

Acknowledgments: The authors wish to thank Gerald Blunden for critical reading of the manuscript and English corrections.

Conflicts of Interest: The authors declare no conflict of interest.

\section{References}

1. Burns, A.; Jacoby, R.; Levy, R. Psychiatric phenomena in Alzheimer's disease. I: Disorders of thought content. Br. J. Psychiatry J. Ment. Sci. 1990, 157, 72-76, 92-94. [CrossRef] [PubMed]

2. Nichols, E.; Szoeke, C.E.I.; Vollset, S.E.; Abbasi, N.; Abd-Allah, F.; Abdela, J.; Aichour, M.T.E.; Akinyemi, R.O.; Alahdab, F.; Asgedom, S.W.; et al. Global, regional, and national burden of Alzheimer's disease and other dementias, 1990-2016: A systematic analysis for the Global Burden of Disease Study 2016. Lancet Neurol. 2019, 18, 88-106. [CrossRef]

3. Cimler, R.; Maresova, P.; Kuhnova, J.; Kuca, K. Predictions of Alzheimer's disease treatment and care costs in European countries. PLoS ONE 2019, 14, e0210958. [CrossRef] [PubMed]

4. Kumar, A.; Singh, A.; Ekavali. A review on Alzheimer's disease pathophysiology and its management: An update. Pharmacol. Rep. PR 2015, 67, 195-203. [CrossRef]

5. Hampel, H.; Mesulam, M.-M.; Cuello, A.C.; Farlow, M.R.; Giacobini, E.; Grossberg, G.T.; Khachaturian, A.S.; Vergallo, A.; Cavedo, E.; Snyder, P.J.; et al. The cholinergic system in the pathophysiology and treatment of Alzheimer's disease. Brain J. Neurol. 2018, 141, 1917-1933. [CrossRef]

6. Zemek, F.; Drtinova, L.; Nepovimova, E.; Sepsova, V.; Korabecny, J.; Klimes, J.; Kuca, K. Outcomes of Alzheimer's disease therapy with acetylcholinesterase inhibitors and memantine. Expert Opin. Drug Saf. 2014, 13, 759-774. [CrossRef]

7. Nachon, F.; Brazzolotto, X.; Trovaslet, M.; Masson, P. Progress in the development of enzyme-based nerve agent bioscavengers. Chem. Biol. Interact. 2013, 206, 536-544. [CrossRef]

8. Nordberg, A.; Ballard, C.; Bullock, R.; Darreh-Shori, T.; Somogyi, M. A Review of Butyrylcholinesterase as a Therapeutic Target in the Treatment of Alzheimer's Disease. Prim. Care Companion CNS Disord. 2013, 15. [CrossRef]

9. Inestrosa, N.C.; Alvarez, A.; Pérez, C.A.; Moreno, R.D.; Vicente, M.; Linker, C.; Casanueva, O.I.; Soto, C.; Garrido, J. Acetylcholinesterase accelerates assembly of amyloid-beta-peptides into Alzheimer's fibrils: Possible role of the peripheral site of the enzyme. Neuron 1996, 16, 881-891. [CrossRef]

10. Babkova, K.; Korabecny, J.; Soukup, O.; Nepovimova, E.; Jun, D.; Kuca, K. Prolyl oligopeptidase and its role in the organism: Attention to the most promising and clinically relevant inhibitors. Future Med. Chem. 2017, 9, 1015-1038. [CrossRef]

11. Szeltner, Z.; Polgár, L. Structure, function and biological relevance of prolyl oligopeptidase. Curr. Protein Pept. Sci. 2008, 9, 96-107. [CrossRef] [PubMed]

12. Wang, S.; Dong, G.; Sheng, C. Structural Simplification of Natural Products. Chem. Rev. 2019, 119, 4180-4220. [CrossRef] [PubMed]

13. Iranshahy, M.; Quinn, R.J.; Iranshahi, M. Biologically active isoquinoline alkaloids with drug-like properties from the genus Corydalis. RSC Adv. 2014, 4, 15900-15913. [CrossRef]

14. Nair, J.J.; van Staden, J. Pharmacological and toxicological insights to the South African Amaryllidaceae. Food Chem. Toxicol. Int. J. Publ. Br. Ind. Biol. Res. Assoc. 2013, 62, 262-275. [CrossRef] 
15. Goietsenoven, G.V.; Mathieu, V.; Lefranc, F.; Kornienko, A.; Evidente, A.; Kiss, R. Narciclasine as well as other Amaryllidaceae Isocarbostyrils are Promising GTP-ase Targeting Agents against Brain Cancers. Med. Res. Rev. 2013, 33, 439-455. [CrossRef]

16. Stafford, G.I.; Pedersen, M.E.; van Staden, J.; Jäger, A.K. Review on plants with CNS-effects used in traditional South African medicine against mental diseases. J. Ethnopharmacol. 2008, 119, 513-537. [CrossRef]

17. Olin, J.; Schneider, L. Galantamine for Alzheimer's disease. Cochrane Database Syst. Rev. 2002, CD001747. [CrossRef]

18. Bastida, J.; Viladomat, F.; Codina, C. Narcissus alkaloids. In Studies in Natural Products Chemistry; Atta-ur-Rahman, Ed.; Structure and Chemistry (Part F); Elsevier: Amsterdam, The Netherlands, 1997; Volume 20, pp. 323-405.

19. Nair, J.J.; Rárová, L.; Strnad, M.; Bastida, J.; van Staden, J. Mechanistic insights to the cytotoxicity of Amaryllidaceae alkaloids. Nat. Prod. Commun. 2015, 10, 171-182. [CrossRef]

20. Bastida, J.; Lavilla, R.; Viladomat, F. Chemical and biological aspects of Narcissus alkaloids. Alkaloids Chem. Biol. 2006, 63, 87-179. [CrossRef]

21. Hulcová, D.; Maříková, J.; Korábečný, J.; Hošt'álková, A.; Jun, D.; Kuneš, J.; Chlebek, J.; Opletal, L.; De Simone, A.; Nováková, L.; et al. Amaryllidaceae alkaloids from Narcissus pseudonarcissus L. cv. Dutch Master as potential drugs in treatment of Alzheimer's disease. Phytochemistry 2019, 165, 112055. [CrossRef]

22. Torras-Claveria, L.; Berkov, S.; Codina, C.; Viladomat, F.; Bastida, J. Daffodils as potential crops of galanthamine. Assessment of more than 100 ornamental varieties for their alkaloid content and acetylcholinesterase inhibitory activity. Ind. Crops Prod. 2013, 43, 237-244. [CrossRef]

23. Breiterová, K.; Ločárek, M.; Kohelová, E.; Talácková, M.; Hulcová, D.; Opletal, L.; Cahlíková, L. Daffodils as Potential Crops of Biologically-active Compounds: Assessment of 40 Ornamental Taxa for their Alkaloid Profile and Cholinesterases Inhibition Activity. Nat. Prod. Commun. 2018, 13. [CrossRef]

24. Pellegrino, S.; Meyer, M.; Zorbas, C.; Bouchta, S.A.; Saraf, K.; Pelly, S.C.; Yusupova, G.; Evidente, A.; Mathieu, V.; Kornienko, A.; et al. The Amaryllidaceae Alkaloid Haemanthamine Binds the Eukaryotic Ribosome to Repress Cancer Cell Growth. Structure 2018, 26, 416-425. [CrossRef]

25. Sener, B.; Orhan, I.; Satayavivad, J. Antimalarial activity screening of some alkaloids and the plant extracts from Amaryllidaceae. Phytother. Res. PTR 2003, 17, 1220-1223. [CrossRef] [PubMed]

26. Havelek, R.; Seifrtova, M.; Kralovec, K.; Bruckova, L.; Cahlikova, L.; Dalecka, M.; Vavrova, J.; Rezacova, M.; Opletal, L.; Bilkova, Z. The effect of Amaryllidaceae alkaloids haemanthamine and haemanthidine on cell cycle progression and apoptosis in p53-negative human leukemic Jurkat cells. Phytomedicine Int. J. Phytother. Phytopharm. 2014, 21, 479-490. [CrossRef] [PubMed]

27. Kohelová, E.; Peřinová, R.; Maafi, N.; Korábečný, J.; Hulcová, D.; Maříková, J.; Kučera, T.; Martínez González, L.; Hrabinova, M.; Vorčáková, K.; et al. Derivatives of the $\beta$-Crinane Amaryllidaceae Alkaloid Haemanthamine as Multi-Target Directed Ligands for Alzheimer's Disease. Molecules 2019, 24, 1307. [CrossRef] [PubMed]

28. Yang, Y.; Huang, S.-X.; Zhao, Y.-M.; Zhao, Q.-S.; Sun, H.-D. Alkaloids from the Bulbs of Lycoris aurea. Helv. Chim. Acta 2005, 88, 2550-2553. [CrossRef]

29. Fan-Chiang, T.-T.; Wang, H.-K.; Hsieh, J.-C. Synthesis of phenanthridine skeletal Amaryllidaceae alkaloids. Tetrahedron 2016, 72, 5640-5645. [CrossRef]

30. Bozkurt, B.; Çoban, G.; Kaya, G.; Onur, M.; Unver-Somer, N. Alkaloid profiling, anticholinesterase activity and molecular modeling study of Galanthus elwesii. South Afr. J. Bot. 2017. [CrossRef]

31. Huang, S.-D.; Zhang, Y.; He, H.-P.; Li, S.-F.; Tang, G.-H.; Chen, D.-Z.; Cao, M.-M.; Di, Y.-T.; Hao, X.-J. A new Amaryllidaceae alkaloid from the bulbs of Lycoris radiata. Chin. J. Nat. Med. 2013, 11, 406-410. [CrossRef]

32. Pigni, N.B.; Ríos-Ruiz, S.; Martínez-Francés, V.; Nair, J.J.; Viladomat, F.; Codina, C.; Bastida, J. Alkaloids from Narcissus serotinus. J. Nat. Prod. 2012, 75, 1643-1647. [CrossRef] [PubMed]

33. Chen, J.-Q.; Xie, J.-H.; Bao, D.-H.; Liu, S.; Zhou, Q.-L. Total Synthesis of (-)-Galanthamine and (-)-Lycoramine via Catalytic Asymmetric Hydrogenation and Intramolecular Reductive Heck Cyclization. Org. Lett. 2012, 14, 2714-2717. [CrossRef] [PubMed] 
34. Berkov, S.; Bastida, J.; Sidjimova, B.; Viladomat, F.; Codina, C. Phytochemical differentiation of Galanthus nivalis and Galanthus elwesii (Amaryllidaceae): A case study. Biochem. Syst. Ecol. 2008, 8, 638-645. [CrossRef]

35. Bohno, M.; Sugie, K.; Imase, H.; Yusof, Y.B.; Oishi, T.; Chida, N. Total synthesis of Amaryllidaceae alkaloids, (+)-vittatine and (+)-haemanthamine, starting from d-glucose. Tetrahedron 2007, 63, 6977-6989. [CrossRef]

36. Ellman, G.L.; Courtney, K.D.; Andres, V.; Feather-Stone, R.M. A new and rapid colorimetric determination of acetylcholinesterase activity. Biochem. Pharmacol. 1961, 7, 88-95. [CrossRef]

37. Vaněčková, N.; Hošt'álková, A.; Šafratová, M.; Kuneš, J.; Hulcová, D.; Hrabinová, M.; Doskočil, I.; Štěpánková, Š.; Opletal, L.; Nováková, L.; et al. Isolation of Amaryllidaceae alkaloids from Nerine bowdenii W. Watson and their biological activities. RSC Adv. 2016, 6, 80114-80120. [CrossRef]

38. Tarrago, T.; Kichik, N.; Seguí, J.; Giralt, E. The Natural Product Berberine is a Human Prolyl Oligopeptidase Inhibitor. ChemMedChem 2007, 2, 354-359. [CrossRef]

39. Breiterová, K.; Koutová, D.; Maříková, J.; Havelek, R.; Kuneš, J.; Majorošová, M.; Opletal, L.; Hošt álková, A.; Jenčo, J.; Řezáčová, M.; et al. Amaryllidaceae Alkaloids of Different Structural Types from Narcissus L. cv. Professor Einstein and Their Cytotoxic Activity. Plants Basel Switz. 2020, 9, 137. [CrossRef]

40. Cahlíková, L.; Hrabinová, M.; Kulhánková, A.; Benesová, N.; Chlebek, J.; Jun, D.; Novák, Z.; Macáková, K.; Kunes, J.; Kuca, K.; et al. Alkaloids from Chlidanthus fragrans and their acetylcholinesterase, butyrylcholinesterase and prolyl oligopeptidase activities. Nat. Prod. Commun. 2013, 8, 1541-1544. [CrossRef]

41. Šafratová, M.; Hoštálková, A.; Hulcová, D.; Breiterová, K.; Hrabcová, V.; Machado, M.; Fontinha, D.; Prudêncio, M.; Kuneš, J.; Chlebek, J.; et al. Alkaloids from Narcissus poeticus cv. Pink Parasol of various structural types and their biological activity. Arch. Pharm. Res. 2018, 41, 208-218. [CrossRef]

42. Nachon, F.; Carletti, E.; Ronco, C.; Trovaslet, M.; Nicolet, Y.; Jean, L.; Renard, P.-Y. Crystal structures of human cholinesterases in complex with huprine $\mathrm{W}$ and tacrine: Elements of specificity for anti-Alzheimer's drugs targeting acetyl- and butyryl-cholinesterase. Biochem. J. 2013, 453, 393-399. [CrossRef] [PubMed]

43. Pohanka, M.; Karasova, J.Z.; Kuca, K.; Pikula, J.; Holas, O.; Korabecny, J.; Cabal, J. Colorimetric dipstick for assay of organophosphate pesticides and nerve agents represented by paraoxon, sarin and VX. Talanta 2010, 81, 621-624. [CrossRef] [PubMed]

44. Hostalkova, A.; Marikova, J.; Opletal, L.; Korabecny, J.; Hulcova, D.; Kunes, J.; Novakova, L.; Perez, D.I.; Jun, D.; Kucera, T.; et al. Isoquinoline Alkaloids from Berberis vulgaris as Potential Lead Compounds for the Treatment of Alzheimer's Disease. J. Nat. Prod. 2019, 82, 239-248. [CrossRef] [PubMed]

45. Cheung, J.; Rudolph, M.J.; Burshteyn, F.; Cassidy, M.S.; Gary, E.N.; Love, J.; Franklin, M.C.; Height, J.J. Structures of human acetylcholinesterase in complex with pharmacologically important ligands. J. Med. Chem. 2012, 55, 10282-10286. [CrossRef] [PubMed]

46. Pettersen, E.F.; Goddard, T.D.; Huang, C.C.; Couch, G.S.; Greenblatt, D.M.; Meng, E.C.; Ferrin, T.E. UCSF Chimera-a visualization system for exploratory research and analysis. J. Comput. Chem. 2004, 25, 1605-1612. [CrossRef] [PubMed]

47. Morris, G.M.; Huey, R.; Lindstrom, W.; Sanner, M.F.; Belew, R.K.; Goodsell, D.S.; Olson, A.J. AutoDock4 and AutoDockTools4: Automated docking with selective receptor flexibility. J. Comput. Chem. 2009, 30, 2785-2791. [CrossRef]

48. Panek, D.; Więckowska, A.; Wichur, T.; Bajda, M.; Godyń, J.; Jończyk, J.; Mika, K.; Janockova, J.; Soukup, O.; Knez, D.; et al. Design, synthesis and biological evaluation of new phthalimide and saccharin derivatives with alicyclic amines targeting cholinesterases, beta-secretase and amyloid beta aggregation. Eur. J. Med. Chem. 2017, 125, 676-695. [CrossRef]

49. Hepnarova, V.; Korabecny, J.; Matouskova, L.; Jost, P.; Muckova, L.; Hrabinova, M.; Vykoukalova, N.; Kerhartova, M.; Kucera, T.; Dolezal, R.; et al. The concept of hybrid molecules of tacrine and benzyl quinolone carboxylic acid (BQCA) as multifunctional agents for Alzheimer's disease. Eur. J. Med. Chem. 2018, 150, 292-306. [CrossRef]

50. Svobodova, B.; Mezeiova, E.; Hepnarova, V.; Hrabinova, M.; Muckova, L.; Kobrlova, T.; Jun, D.; Soukup, O.; Jimeno, M.L.; Marco-Contelles, J.; et al. Exploring Structure-Activity Relationship in Tacrine-Squaramide Derivatives as Potent Cholinesterase Inhibitors. Biomolecules 2019, 9, 379. [CrossRef] 
51. O'Boyle, N.M.; Banck, M.; James, C.A.; Morley, C.; Vandermeersch, T.; Hutchison, G.R. Open Babel: An open chemical toolbox. J. Cheminformatics 2011,3, 33. [CrossRef]

52. Trott, O.; Olson, A.J. AutoDock Vina: Improving the speed and accuracy of docking with a new scoring function, efficient optimization and multithreading. J. Comput. Chem. 2010, 31, 455-461. [CrossRef] [PubMed]

(C) 2020 by the authors. Licensee MDPI, Basel, Switzerland. This article is an open access article distributed under the terms and conditions of the Creative Commons Attribution (CC BY) license (http://creativecommons.org/licenses/by/4.0/). 